\title{
Stability-Indicating HPLC Assay and Stability Study Over Two Years of Morphine Hydrochloride Diluted Solutions in Polypropylene Syringes
} d'Hayer B*, Vieillard V, Astier A and Paul M

Laboratory control, Department of Pharmacy, Centre Hospitalier Universitaire Henri Mondor, 51 avenue du Maréchal de Lattre de Tassigny, 94010 Créteil Cedex, France

\begin{abstract}
In the context of a clinical trial involving the production of a hospital preparation, the stability of a solution of morphine hydrochloride diluted in normal saline solution at a concentration of $0.33 \mathrm{mg} / \mathrm{mL}$ and contained in polypropylene syringes of $3 \mathrm{~mL}$ was studied over a period of two years. Three batches of syringes were manufactured and stored away from light at $+5^{\circ} \mathrm{C}$ at $+22^{\circ} \mathrm{C}$, and in a climatic chamber at $+40^{\circ} \mathrm{C}$ with $75 \%$ relative humidity. The development of a stability-indicating assay of morphine hydrochloride by an ion-pair reversed-phase polarity high performance liquid chromatography, the measurement of $\mathrm{pH}$ and osmolality, and the macroscopic and microscopic observation of the solutions were used to assess the stability of the samples. Chemical and physical stability studies have shown that solutions of morphine hydrochloride diluted in $0.9 \% \mathrm{NaCl}$ at a concentration of $0.33 \mathrm{mg} / \mathrm{mL}$ in polypropylene syringes are stable up to two years when syringes are stored away from light at $+5^{\circ} \mathrm{C}$ or at $+22^{\circ} \mathrm{C}$.
\end{abstract}

Keywords: Morphine hydrochloride; HPLC; Stability-indicating method; Assay method; Polypropylene syringe

\section{Introduction}

Morphine is commonly used as a level III analgesic (WHO classification) to treat severe and/or refractory pain to analgesics of lower level. Morphine also offers new opportunities as a postconditioning agent with cardioprotective effect in myocardial infarction [1]. Indeed, if the early reopening of the occluded coronary artery can limit the extent of damage caused by myocardial ischemia, it is also established that reperfusion induced by itself organic and functional damages [2]. However, the opiate agonists by binding to delta and kappa myocardial receptor activate several signaling pathways involved in cardioprotection as the RISK one (standing for Reperfusion Injury Salvage Kinase: ERK1/2, Akt/PI3K/mTOR, PKC) [3]. This cardioprotective effect is mediated by the inhibition of the opening of the permeability transition pore and by the opening of potassium channels of mitochondria [4]. In addition, activation of delta and kappa receptor by opioid agonists inhibits the adhesion of neutrophil granulocytes and decreases the cytotoxic action of cytokines associated with reperfusion [5]. The protective action of morphine in pre- or post-conditioning ischemia has been demonstrated in vivo in animal models $[3,4,6,7]$. This prompted the Société Française de Cardiologie to promote a randomized, controlled, double-blind, multicenter study. The MIAMI clinical trial (standing for "Morphine in Acute Myocardial Infarction") main objective is to evaluate in humans the therapeutic benefit of the post-conditioning by morphine at the time of the revascularization of the impaired coronary artery during a heart attack infarction. The administration of placebo, which is normal saline solution, or of a $0.33 \mathrm{mg} / \mathrm{mL}$ morphine hydrochloride solution is achieved by injecting the contents of a $3 \mathrm{~mL}$ polypropylene syringe during the flow interrupted angioplasty protocol. The clinical trial requires the production of a hospital preparation in a sterile unit, which consists of two batches of syringes containing either the placebo either the verum: the solution of morphine hydrochloride. To meet the regulatory requirements of Good Manufacturing Practices (GMPs), the stability of the preparation was studied over time. In the literature, the stability of solutions of morphine $\geq 1 \mathrm{mg} / \mathrm{mL}$ is validated beyond six months [8]. However, for more diluted solutions, few data are available. Therefore, a stability-indicating high performance liquid chromatography assay (HPLC) has been developed in order to study the stability of morphine hydrochloride diluted solutions $(0.33 \mathrm{mg} /$ $\mathrm{mL}$ ) contained in polypropylene syringes for a period of two years.

\section{Materials and Methods}

\section{Samples preparation}

Three batches were prepared in the same way as those prepared for the clinical trials. The syringes of $0.33 \mathrm{mg} / \mathrm{mL}$ morphine solution were manufactured in an ISO class 5 clean room in a laminar flow hood with the following process and according to the GMPs:

For each batch, $50 \mathrm{~mL}$ of $0.9 \% \mathrm{NaCl}$ isotonic solution for injection were taken from a bag of $250 \mathrm{~mL}$ (Fresenius Kabi Freeflex ${ }^{\mathbb{B}}$ ) and then introduced into an empty sterile bag of $100 \mathrm{~mL}$ (Macoflex ${ }^{\circledR}$, Macopharma). $3.5 \mathrm{~mL}$ of morphine hydrochloride (glass ampoules $10 \mathrm{mg} / \mathrm{mL}, 1 \mathrm{~mL}$ for injection, CDM Lavoisier), corresponding to an amount of $35 \mathrm{mg}$ of morphine hydrochloride were mixed with 52.5 $\mathrm{mL}$ of $0.9 \% \mathrm{NaCl}$ in a $60 \mathrm{~mL}$ syringe and then injected into the $100 \mathrm{~mL}$ bags already containing a $50 \mathrm{~mL}$ of $0.9 \% \mathrm{NaCl}$ solution. The volume of each bag was distributed in sterile polypropylene syringes $\left(3 \mathrm{~mL} \mathrm{BD}{ }^{\mathrm{TM}}\right.$ syringes in polypropylene with BD Luer-Lok ${ }^{\mathrm{TM}}$ tip). Finally, syringes were sealed with sterile closures (universal obturator didactic ${ }^{\circledR}$ male/ female in polyethylene).

\section{Storage conditions}

Syringes of each batch were labelled, weighed, then stored in

*Corresponding author: d'Hayer B, Department of Pharmacy, Centre Hospitalier Universitaire Henri Mondor, 51 avenue du Maréchal de Lattre de Tassigny, 94010 Créteil Cedex, France, E-mail: benoit.d-hayer@outlook.com

Received January 10, 2013; Accepted January 30, 2013; Published February 04, 2013

Citation: d'Hayer B, Vieillard V, Astier A, Paul M (2013) Stability-Indicating HPLC Assay and Stability Study Over Two Years of Morphine Hydrochloride Diluted Solutions in Polypropylene Syringes. Pharmaceut Anal Acta 4: 205. doi:10.4172/2153-2435.1000205

Copyright: ( 2013 d'Hayer B, et al. This is an open-access article distributed under the terms of the Creative Commons Attribution License, which permits unrestricted use, distribution, and reproduction in any medium, provided the original author and source are credited. 
a thermally sealed bag and placed away from light. Temperature conditions for long term studies were $+5^{\circ} \mathrm{C} \pm 3^{\circ} \mathrm{C}$ (fridge $\mathrm{ML}$ 1200 Electrolux $^{\circledR}$ ) according to the international conference on harmonisation requirements (ICH) [9], and $+22^{\circ} \mathrm{C}$ in a controlled atmosphere room (pressure and temperature) used to store drugs for clinical trial. For the accelarated study, storage conditions were $+40^{\circ} \mathrm{C} \pm$ $2^{\circ} \mathrm{C}$ with $75 \% \pm 5 \%$ relative humidity $(\mathrm{RH})$ in an ICH climatic chamber (Climacell MMM Medcenter ${ }^{\mathbb{R}}$ ) according to ICH requirements [9].

\section{Analysis and frequency}

Time points of analysis were Day 0 (D0), 1 ,2, 3, 4, 6 months, 1 1.5 and 2 years for long term studies. They were D0, 7, 15 days, 1 , $1.5,2,3,4,6$ months, 1 year for the accelerated study. At each time, samples were examined for the following parameters: macroscopic and microscopic aspects, water loss for syringes stored at $+22^{\circ} \mathrm{C}$ and $+40^{\circ} \mathrm{C}$, $\mathrm{pH}$, osmolality, assay and detection of impurities and degradation products of morphine by HPLC. According to the ICH requirements [9], assays were performed on the minimum periods for studies of long-term stability (1 year) and of accelerated stability (6 months). Minimum frequencies analysis, three months the first year and six months in the second year of the study were also observed. A higher frequency of analysis has been implemented during the first year in order to highlight a possible instability as suggested by the color change of morphine hydrochloride solution at $2 \mathrm{mg} / \mathrm{mL}$ revealed after six days of storage at $+25^{\circ} \mathrm{C}$ and $+40^{\circ} \mathrm{C}$ by Le Hoang et al. [10].

Some samples were frozen at $-20^{\circ} \mathrm{C}$ and thawed prior to assay.

Sterility was tested at day 0 and after 1 year, 1.5 years and 2 years.

\section{Physical stability assessment}

Evaluation of the physical stability included a macroscopic and a microscopic analysis of morphine hydrochloride solutions. Macroscopic observation was conducted by a detection of visible particles using a candling table according to the method described in the European Pharmacopoeia Chapter 2.9.20. Moreover, an observation on white background to look for a color change was carried out, in comparison to a freshly prepared $0.33 \mathrm{mg} / \mathrm{mL}$ morphine hydrochloride solution in $0.9 \% \mathrm{NaCl}$. An optical system for acquisition and image processing has enabled the microscopic analysis of the solutions (Olympus IM inverted microscope, 2.5x eyepiece projection, density filter, digital color camera Sony with sensor $1 / 1 / 8$ XCD100 C-mount, Nazca driver, software for acquisition and image processing Ellix ${ }^{\mathrm{TM}}$, Microvision Instruments ${ }^{\circledR}$, ZI petite montagne Sud CE1750 - 8, rue du Forez 91047 Evry Cedex, France). The standard used is described in Section 2.B of Chapter 2.9.19 of the European Pharmacopoeia for injectable solutions packaged in containers of nominal volume of less than $100 \mathrm{~mL}$. The average number of particles examined in the units must be $\leq 3000$ for particles size $\geq 10 \mu \mathrm{m}$ and $\leq$ 300 for particles size $\geq 25 \mu \mathrm{m}$. Water loss measurement of each sample was used to check that no critical change has occurred during storage, and to calculate the "true" concentration of morphine hydrochloride in the $0.9 \% \mathrm{NaCl}$ solution. It was conducted by weighing each syringe at day 0 and at the time of analysis, and by making the difference between the two weights.

\section{Chemical stability assessment}

Chemical stability was first assessed by a measure of $\mathrm{pH}$ ( $\mathrm{pH}$ meter Consort ${ }^{\circledR}$ P901 connected to a micro-combined glass $\mathrm{pH}$ electrode Fisher Scientific ${ }^{\circledR}$ W84909) and of osmolality (Automatic Osmometer Roebling $\left.^{\mathbb{}}\right)$. Then, concentrations of morphine, identification and quan- tification of its impurities and its degradation products were performed by a method of ion-pair reversed-phase HPLC based on previous works of Nguyen-Xuan [8] and Hung [11].

\section{Mobile phase composition}

$62.5 \% \mathrm{v} / \mathrm{v}$ acetate buffer $0.5 \mathrm{M}, \mathrm{pH} 4.2$, filtered through $0.22 \mu \mathrm{m}$ membrane filter (MILLIPORE, type GS, $\varnothing 0.22 \mu \mathrm{m}$ ):

$13.7 \mathrm{~mL}$ of glacial acetic acid (RP Normapur ${ }^{\circledR}$ Prolabo) $\mathrm{VWR}^{\circledR}$ )

$5.683 \mathrm{~g}$ of ammonium acetate (98.2\% purity, AnalaR Normapur

$1.457 \mathrm{~g}$ of sodium dodecyl sulfate (98\% purity, GPR Rectapur $\mathrm{VWR}^{\circledR}$ ) Q.S. $625 \mathrm{~mL}$ sterile water (Versylene ${ }^{\circledR}$ Fresenius or Versol) grade)

$37.5 \% \mathrm{v} / \mathrm{v}$ acetonitrile $(375 \mathrm{~mL})$ (CHROMASOLV ${ }^{\circledR}$ Gradient

Acetate buffer and acetonitrile were mixed and sonicated to degas the mobile phase.

\section{Apparatus}

- Dionex ${ }^{\circledR}$ HPLC system: pump, autosampler, column compartment, detector (UltiMate ${ }^{\circledR} 3000$ modules). The detector used was a UV-visible spectrophotometer (Variable Wavelength Detector ${ }^{\mathbb{R}}$ ) able to analyze simultaneously a sample at 4 wavelengths. The entire system is controlled by the driver and analysis software Chromeleon ${ }^{\circledR}$.

- Jasco ${ }^{\circledR}$ HPLC system: autosampler AS-1555-10, pump PU-980, detector UV-975.

- Column C18 250×4,6 mm, 5 m Interchim ${ }^{\circledR}$ Modulo-Cart QK Strategy $1005 \mathrm{C} 18$

\section{Chromatographic conditions}

- Flow rate, $1 \mathrm{~mL} / \mathrm{min}$ and isocratic elution

- Injected volume, $100 \mu \mathrm{L}$

- Column temperature, $+25^{\circ} \mathrm{C}$

- Run time, 15 min

- Wavelengths of detection: $210 \mathrm{~nm}, 254 \mathrm{~nm}$ and $285 \mathrm{~nm}$

\section{Methods}

Samples diluted to $1: 10$ at the concentration of $33 \mu \mathrm{g} / \mathrm{mL}$, were analyzed at three wavelengths corresponding to morphine hydrochloride absorption maxima determined by a spectrophotometer UV-visible coupled to infrared (Microdom ${ }^{\circledR}$ and analysis software Multispec $^{\circledR}$ ).

Morphine hydrochloride $(\mathrm{MH})$ concentrations were measured at $285 \mathrm{~nm}$. Wavelengths $210 \mathrm{~nm}$ and $254 \mathrm{~nm}$ were used in addition to detection at $285 \mathrm{~nm}$ to identify and quantify impurities and main degradation products of morphine: morphine $\mathrm{N}$-oxide, pseudomorphine, codeine and apomorphine $[8,10,11]$.

According to $\mathrm{ICH}$ requirements [12], the calibration curve was obtained by assaying five calibration standards in aqueous solution at concentrations extended over a range of at least $33 \mu \mathrm{g} / \mathrm{mL} \pm 30 \%$ (20, $30,33,40,50 \mu \mathrm{g} / \mathrm{mL})$. In order to validate the chromatographic method, as recommended by "Société Française des Sciences et Techniques Pharmaceutiques" (SFSTP) [13], each point of the range was repeated 
three times to check the linearity of the method in the range of analysis. The calibration curve concentrations were plotted against areas under the curves.

After the validation of the HPLC method, points of the calibration range were then passed once each, and the assay was validated by measuring a sample of quality control at the beginning and the end of the series analysis. The calibration range was remade when the measured concentration of a quality control sample was not validated two times.

Dilutions of the main degradation products and impurities of morphine were prepared to allow their identification and quantification:

Solution of apomorphine hydrochloride at $1 \mathrm{mg} / \mathrm{mL}: 1 \mathrm{~mL}$ of apomorphine hydrochloride solution (APOKINON ${ }^{\circledR} 10 \mathrm{mg} / \mathrm{mL}, 5 \mathrm{~mL}$ for subcutaneous injection) was diluted Q.S. $10 \mathrm{~mL}$ of sterile water.

Solution of codeine at $7 \mathrm{mg} / \mathrm{mL}$ : $70 \mathrm{mg}$ of codeine base (raw materials of quality control laboratory, pharmacy, Henri Mondor hospital, Créteil, France) was dissolved Q.S. $10 \mathrm{~mL}$ of ethanol $60 \% \mathrm{v} / \mathrm{v}$.

Solution of pseudomorphine at $1 \mathrm{mg} / \mathrm{mL}: 10 \mathrm{mg}$ of pseudomorphine base (kindly supplied by Dominique Pradeau, AGEPS, Paris, France), a drop of $25 \%$ ammonia solution and a drop of $38 \%$ potassium hydroxide solution were dissolved Q.S. $10 \mathrm{~mL}$ of sterile water.

These solutions were diluted and analyzed to study the resolution of the chromatographic system for these compounds and to determine their limits of quantification.

Morphine $\mathrm{N}$-oxide is described in the literature with pseudomorphine as the most easily formed degradation product of morphine [14]. To obtain morphine N-oxide, solutions of $0.5 \mathrm{mg} / \mathrm{mL}$ morphine hydrochloride were stored at +90 (drying oven Memmert ${ }^{\mathbb{R}}$ modell 200) for 24 hours in forced degradation conditions $(0.05 \mathrm{~N} \mathrm{HCl}$ or $0.05 \mathrm{~N} \mathrm{NaOH}$ or $3 \%$ hydrogen peroxide) based on previous works of Lee and Sabra [15] and Hildebrand et al. [16]. These solutions were diluted and analyzed to study the resolution of the chromatographic system for the degradation products formed.

The purpose was to demonstrate that the HPLC analysis used was able to highlight the appropriate degradation products of morphine and verify that the method was stability-indicating.

\section{Microbiological stability assessment}

Sterility tests were realized according to the method described in the European Pharmacopoeia.

\section{Results}

\section{Stability-Indicating validation of the HPLC method}

In the chromatographic conditions previously detailed, the method was able to separate with a good resolution $(\mathrm{R}>1.5)$ the identified peaks of morphine, codeine, pseudomorphine and apomorphine obtained separately or when these impurities or degradation products were mixed to $\mathrm{MH}$ (Figure 1). The study conducted in forced degradation conditions $(\mathrm{HCl} 0.05 \mathrm{~N}$ or $\mathrm{NaOH} 0.05 \mathrm{~N}$ or hydrogen peroxide $3 \%$ ) at $+90^{\circ} \mathrm{C}$ for $24 \mathrm{~h}$ showed that the peak of morphine was well separated from peaks of the formed degradation products, identified or not, with a resolution $>1.5$. Only solutions exposed to soda and hydrogen peroxide had a significant alteration in the amount of morphine. Losses were $98.4 \%$ in the presence of sodium hydroxide, $95.2 \%$ in the presence of hydrogen peroxide, and $<1 \%$ in the presence of $\mathrm{HCl}$.

Based on ICH requirements [12], the precision of the assay method was evaluated at different days, mobile phases, calibration curves, analysts, by the repeatability ( 3 points of the range, $n=3$ ) $C V=0.87 \%$, and by the global intermediate precision $(n=9) C V=1.96 \%$.

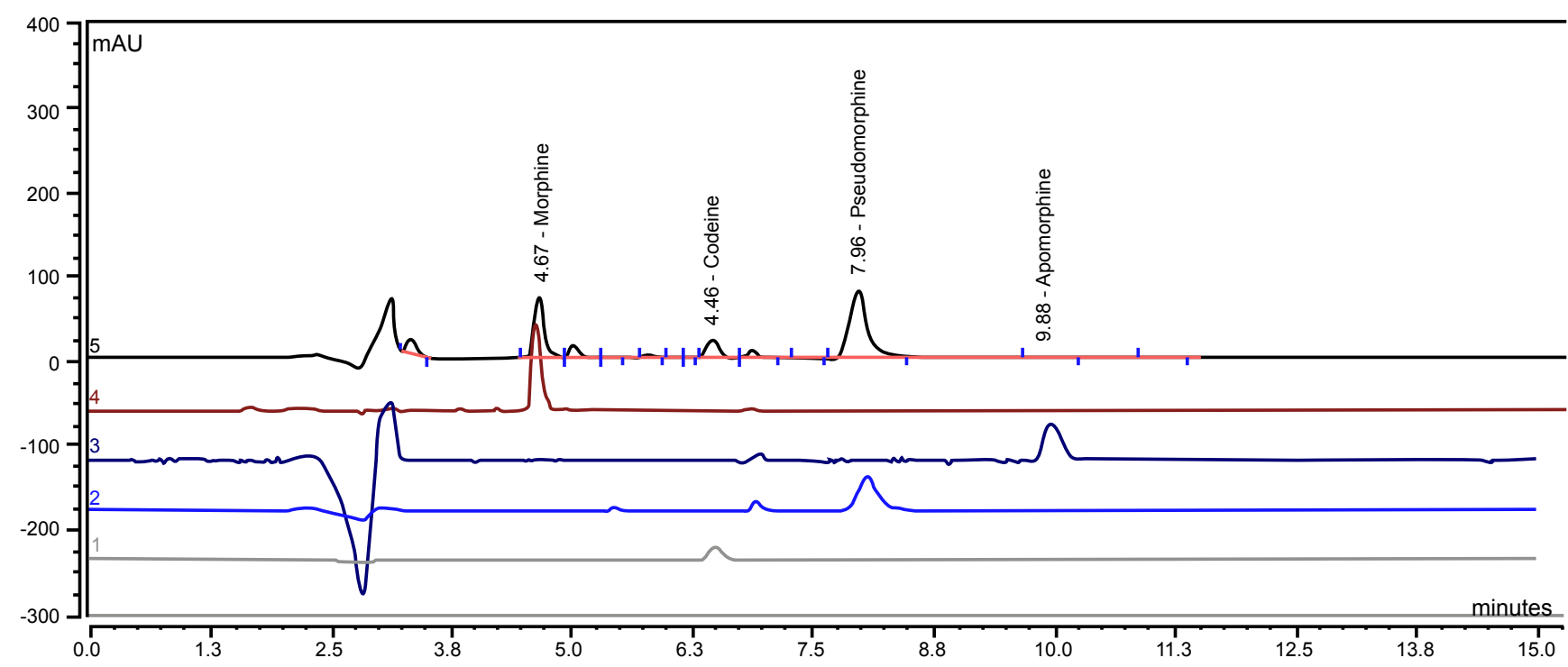

Figure 1: Peaks resolution of the HPLC method: $R>1,5$ Chromatograms,

1. Codeine $5 \mu \mathrm{g} / \mathrm{mL}(285 \mathrm{~nm})$

2. Pseudomorphine $5 \mu \mathrm{g} / \mathrm{mL}(254 \mathrm{~nm})$

3. Apomorphine $5 \mu \mathrm{g} / \mathrm{mL}(210 \mathrm{~nm})$

4. Morphine $33 \mu \mathrm{g} / \mathrm{mL}(285 \mathrm{~nm})$

5. Mixed solution : Morphine $33 \mu \mathrm{g} / \mathrm{mL}$ in stress condition, Codeine $7 \mu \mathrm{g} / \mathrm{mL}$,

Pseudomorphine $10 \mu \mathrm{g} / \mathrm{mL}$, Apomorphine $1 \mu \mathrm{g} / \mathrm{mL}(254 \mathrm{~nm})$ 
Linearity of the method ( 5 points, $n=3$ ) across a range of 20 to 50 $\mu \mathrm{g} / \mathrm{mL}$, was defined as follow: coefficient of correlation $\mathrm{R}^{2}=0.999727$, $\mathrm{y}$-intercept $=0.0715$, and slope $=0.3857$ (Figure 2). A range performed on the Jasco ${ }^{\circledR}$ HPLC system has confirmed the linearity of the method $\left(\mathrm{R}^{2}=0.999553\right)$.

Accuracy of the technique was determined by the recovery percentage $(\mathrm{Y})$. Y $(\mathrm{n}=13, \mathrm{p}=0.05)$ was $100.6 \pm 1.3 \%$ on the Dionex ${ }^{\mathbb{B}}$ HPLC system.

Limits of detection (DL) and quantification (QL) of the morphine degradation products and impurities, calculated thanks to the standard deviation of the response and the slope, were dependant of the wavelength. Best limits were $\mathrm{DL}=3.15$ and $\mathrm{QL}=9.54 \mu \mathrm{g} / \mathrm{mL}$ for codeine at $285 \mathrm{~nm}, \mathrm{DL}=0.19$ and $\mathrm{QL}=0.59 \mu \mathrm{g} / \mathrm{mL}$ for pseudomorphine at 254 $\mathrm{nm}$ and $\mathrm{DL}=0.68$ and $\mathrm{QL}=2.07 \mu \mathrm{g} / \mathrm{mL}$ for apomorphine at $210 \mathrm{~nm}$.

In addition, the impact of freezing-thawing process of some analysis conditions on the result of the assay has been evaluated. A Student's test on pairwise data $(n=6$, degrees of freedom $=2)$ concluded to the absence of significant variation on the morphine assay before or after freezing and thawing a sample $(\mathrm{t}=-1.9289, \mathrm{p}=0.1935)$.

The method was specific, precise, and accurate according to $\mathrm{ICH}$ criteria [12]. In view of these results, the chromatographic method has been validated stability-indicating and samples of the stability study could be analyzed.

Two years stability study of $0.33 \mathrm{mg} / \mathrm{mL}$ morphine hydrochloride in $\mathbf{0 . 9 \%}$ sodium chloride solution

After six months, the water loss of polypropylene syringes sealed with sterile closures was below $0.2 \%$ for solutions stored at $+22^{\circ} \mathrm{C}$ and was below $0.6 \%$ for solutions stored at $+40^{\circ} \mathrm{C}$. After 2 years, the water loss was below $0.7 \%$ in all temperature conditions except for one sample stored one year at $+40^{\circ} \mathrm{C}$ and which has suffered a loss in water $>10 \%$. This result may suggest that the syringe was badly clogged at day 0 or that the closure had a defect.

\section{Chemical stability analysis}

- $\mathrm{pH}$ measurements showed for all batches an initial alkalinization of solutions of $\mathrm{pH} 5.4$ at day 0 , after one week of storage at $+40^{\circ} \mathrm{C}$ and after one month at $+5^{\circ} \mathrm{C}$ and at $+22^{\circ} \mathrm{C}$. $\mathrm{pH}$ values reached, $5.9 \pm 0.1$ at $+5^{\circ} \mathrm{C}, 6.1 \pm 0.2$ at $+22^{\circ} \mathrm{C}$, and $6.2 \pm 0.4$ at $+40^{\circ} \mathrm{C}(\mathrm{p}=0.05)$, and remained quite stable thereafter $(\sigma=0.2$ at $+5^{\circ} \mathrm{C}, \sigma=0.4$ at $+22^{\circ} \mathrm{C}$ ). It was not the same for syringes stored at $+40^{\circ} \mathrm{C}$, whose $\mathrm{pH}$ began to decrease after 3 months and was 4.8 after one year of storage $(\sigma=0.6)$.

- Measurements of osmolality showed a slight increase of the osmolality at day $0(270 \mathrm{mOsm} / \mathrm{kg})$, after a week of storage at $+40^{\circ} \mathrm{C}$ and after a month at $+5^{\circ} \mathrm{C}$ and $+22^{\circ} \mathrm{C}$. But values of osmolality remained quite stable at $279 \pm 2 \mathrm{mOsm} / \mathrm{kg}(\mathrm{p}=0.05)$.

- Data for the determination of morphine hydrochloride concentrations by HPLC were not significantly different between batches (Wilcoxon test, $\mathrm{p}=0.3823$ at $+5^{\circ} \mathrm{C}, \mathrm{p}=0.1049$ at $+22^{\circ} \mathrm{C}, \mathrm{p}=0.1615$ at $+40^{\circ} \mathrm{C}$ ) and mean concentrations were $(\mathrm{p}=0.05) 98.3 \pm 1.4 \%$ at $+5^{\circ} \mathrm{C}, 98.8 \pm 1.4 \%$ at $+22^{\circ} \mathrm{C}$ and $94.2 \pm$ $3.9 \%$ at $+40^{\circ} \mathrm{C}$.

- Codeine, pseudomorphine and apomorphine were not detected at the detection and quantification limits of the method for samples stored at $+5^{\circ} \mathrm{C}$ and $+22^{\circ} \mathrm{C}$. Secondary peaks of morphine hydrochloride were observed at 210, 254,

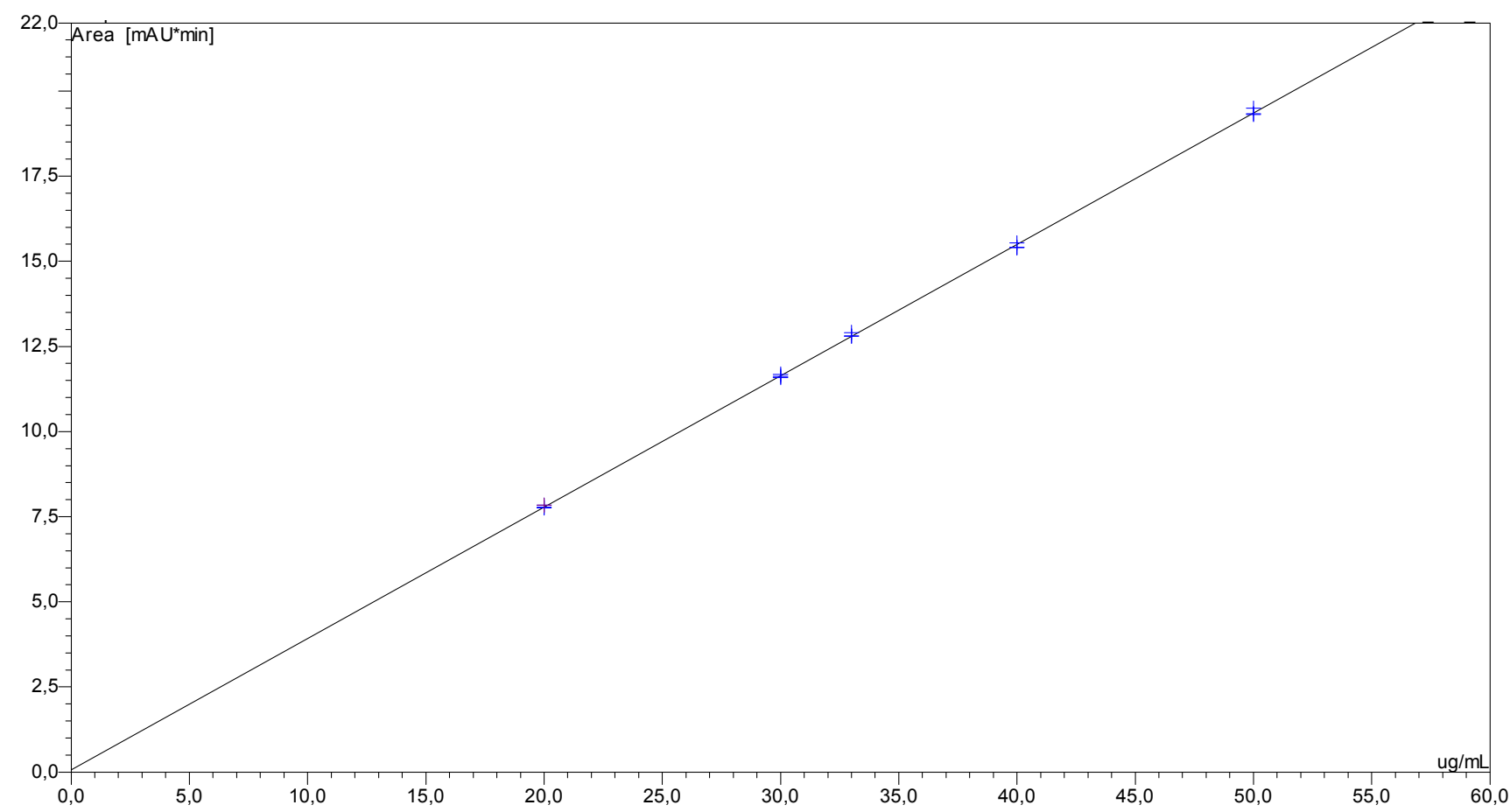

Figure 2: Calibration curve of the HPLC assay method. Calibration standards are $20,30,33,40,50 \mu \mathrm{g} / \mathrm{mL}$ of morphine hydrochloride in aqueous solution $(100 \%=$ $33 \mu \mathrm{g} / \mathrm{mL})$. 
and $285 \mathrm{~nm}$ in samples stored at $+40^{\circ} \mathrm{C}$ but except for codeine, they cannot be identified and accounted all together for less than $5 \%$ of the total area under the curve (Figure 3).

\section{Physical stability analysis}

Macroscopic observation of morphine hydrochloride solutions did not reveal the presence of visible particles in syringes. Solutions stored at $+5^{\circ} \mathrm{C}$ and $+22^{\circ} \mathrm{C}$ remained clear and colorless during the two years of the study. Solutions stored at $+40^{\circ} \mathrm{C}$ while remaining clear, have developed a "slightly yellow" color since the third month of the study. Microscopic analysis performed on four fields for solutions stored at $+40^{\circ} \mathrm{C}$ did not reveal the presence of any particle of size $\geq 10 \mu \mathrm{m}$ or $\geq$ $25 \mu \mathrm{m}$.

Finally, data showed that microbiological testing solutions were sterile after 2 years of conservation.

\section{Discussion}

The chromatographic method developed had limits of detection and quantification higher than those described by Le Hoang et al. [10] but equivalent to those from the work of Nguyen-Xuan et al. [8]. The evolution of the $\mathrm{pH}$ of the $0.33 \mathrm{mg} / \mathrm{mL}$ morphine hydrochloride in $0.9 \% \mathrm{NaCl}$ solutions showed an alkalinization of $\mathrm{pH}$ compared to day 0 , while $\mathrm{pH}$ was stable over time for solutions stored at $+5^{\circ} \mathrm{C}$ and $+22^{\circ} \mathrm{C}$. These results are in contradiction with the study of Lee et al. [15] that shows an acidification of 2 and $3 \mathrm{mg} / \mathrm{mL}$ morphine sulfate solutions after one month of storage at $+4^{\circ} \mathrm{C}$ and $+25^{\circ} \mathrm{C}$. Acidification of the solution of morphine hydrochloride was still observed for syringes stored for more than three months at $+40^{\circ} \mathrm{C}$. As well as $\mathrm{pH}$, osmolality has changed in morphine solutions and has increased since day 0 , while being stable over time and in the range of the defined acceptance criteria which was $270 \mathrm{mOsm} / \mathrm{kg} \pm 10 \%$.

For the two years of the stability study, in contrast to previous works $[8,10,11,16]$ on more concentrated solutions of morphine, no traces of the main degradation products morphine have been found in the solutions analyzed at $+5^{\circ} \mathrm{C}$ and $+22^{\circ} \mathrm{C}$. Results brought by the study in forced degradation conditions $(0.05 \mathrm{~N} \mathrm{HCl}$ or $0.05 \mathrm{~N}$ $\mathrm{NaOH}$ or $3 \%$ hydrogen peroxide) were consistent with previously published results by Hildebrand et al. [16]. They suggest that morphine hydrochloride solutions are more stable in acidic solution and must be protected from oxidation (UV, air). Although an alkalinization of the morphine hydrochloride solutions was observed at $+5^{\circ} \mathrm{C}$ and $+22^{\circ} \mathrm{C}$, $\mathrm{pH}$ values remained in the acidic range $(\mathrm{pH}<7)$ and therefore did not promote the degradation of morphine. Assays of morphine solutions showed no significant difference from the average concentration at day 0 for samples stored at $+5^{\circ} \mathrm{C}$ and $+22^{\circ} \mathrm{C}$. On the contrary at $+40^{\circ} \mathrm{C}$, a decrease in the content of morphine hydrochloride has been highlighted. However, series of analysis were validated when the two quality controls had accuracy within $\pm 5 \%$. In this condition, a significant decrease $(>5 \%)$ of morphine hydrochloride content was only observed since the second month of the study at $+40^{\circ} \mathrm{C}$. For the other assays, the observed variability was probably due to the inter-sample and to the inter-analysis variability. Finally, during the study, concentrations of solutions stored at $+5^{\circ} \mathrm{C}$ and $+22^{\circ} \mathrm{C}$ were in the range of the defined acceptance criteria of initial concentration $\pm 5 \%$ as generally admitted by ICH criteria [9]. During

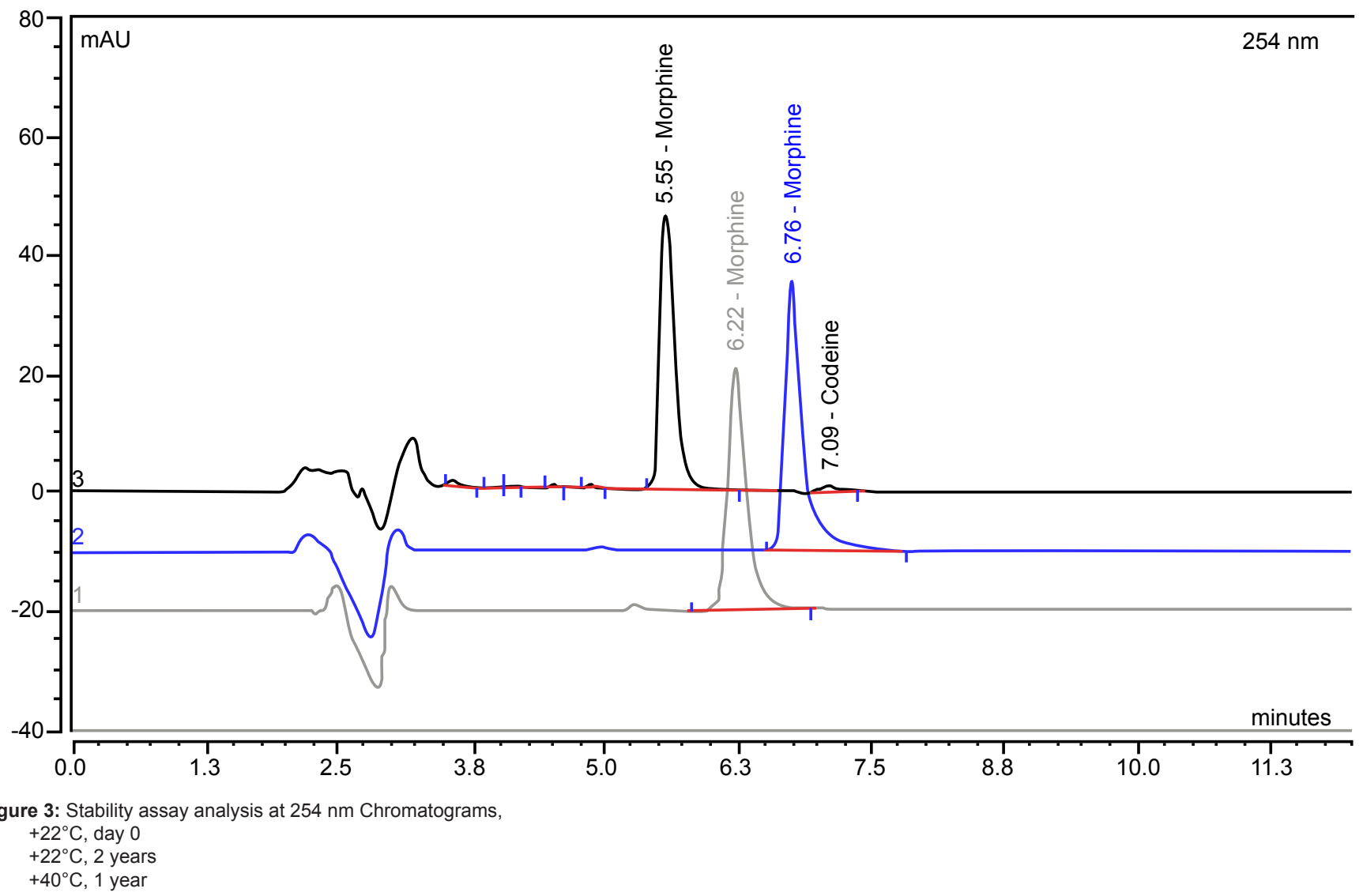


Citation: d'Hayer B, Vieillard V, Astier A, Paul M (2013) Stability-Indicating HPLC Assay and Stability Study Over Two Years of Morphine Hydrochloride Diluted Solutions in Polypropylene Syringes. Pharmaceut Anal Acta 4: 205. doi:10.4172/2153-2435.1000205

the study, the release of impurities from polypropylene syringes and morphine hydrochloride adsorption on polypropylene have not been evaluated. However, a previous study [17] analyzes the influence of the packaging on the stability of concentrated morphine solutions. This study shows that the polypropylene is a conditioning agent that is as suitable as borosilicate glass at $+4^{\circ} \mathrm{C}$ and $+22^{\circ} \mathrm{C}$ and that $\mathrm{PVC}$ remains the agent that causes more instability. As regards the adsorption of a morphine hydrochloride solution at the surface of polypropylene syringes, it is described in Remington [18], that the adsorption phenomenon is very unlikely since the solvent and the solute are chemically compatible, and the conditioning agent and the solvent are chemically different. So, aqueous solutions of salts of morphine should not have any interaction with polypropylene which is a non-ionic hydrophobic substance. In addition, variations of concentrations during the study were not consistent with an adsorption-desorption phenomenon.

\section{Conclusion}

Thanks to the development of a stability-indicating HPLC assay, the chemical and physical stability studies of diluted morphine solutions have shown that solutions of morphine hydrochloride diluted in $0.9 \%$ $\mathrm{NaCl}$ at a concentration of $0.33 \mathrm{mg} / \mathrm{mL}$ in polypropylene syringes were stable up to two years when syringes are kept away from light at $+5^{\circ} \mathrm{C}$ or at $+22^{\circ} \mathrm{C}$. In addition, the microbiological quality of samples has been demonstrated for a period of two years. Consequently, the shelf-life of diluted morphine hydrochloride solutions contained in well-clogged polypropylene syringes could be extended to two years when they are prepared according to the GMPs and stored away from light at $+5^{\circ} \mathrm{C} \pm$ $3^{\circ} \mathrm{C}$ or at $+22^{\circ} \mathrm{C}$.

\section{References}

1. Schultz JE, Rose E, Yao Z, Gross GJ (1995) Evidence for involvement of opioid receptors in ischemic preconditioning in rat hearts. Am J Physiol 268: $2157-$ 2161.

2. Piper HM, García-Dorado D, Ovize M (1998) A fresh look at reperfusion injury. Cardiovasc Res 38: 291-300.

3. Gross ER, Hsu AK, Gross GJ (2004) Opioid-induced cardioprotection occurs via glycogen synthase kinase beta inhibition during reperfusion in intact rat hearts. Circ Res 94: 960-966.

4. Obame FN, Plin-Mercier C, Assaly R, Zini R, Dubois-Randé JL, et al. (2008) Cardioprotective effect of morphine and a blocker of glycogen synthase kinase
3 beta, SB216763 [3-(2,4-dichlorophenyl)-4(1-methyl-1H-indol-3-yl)-1Hpyrrole-2,5-dione], via inhibition of the mitochondrial permeability transition pore. J Pharmacol Exp Ther. 326: 252-258.

5. Wang TL, Chang $H$ (2001) Intravenous morphine reduces plasma endothelin 1 concentration through activation of neutral endopeptidase 24.11 in patients with myocardial infarction. Ann Emerg Med 37: 445-449.

6. Barron BA (2000) Cardiac opioids. Proc Soc Exp Biol Med 224: 1-7

7. Gross ER, Hsu AK, Gross GJ (2007) GSK3beta inhibition and K(ATP) channe opening mediate acute opioid-induced cardioprotection at reperfusion. Basic Res Cardiol 102: 341-349.

8. Nguyen-Xuan T, Griffiths W, Kern C, Van Gessel E, Bonnabry P (2006) Stability of Morphine Sulfate in Polypropylene Infusion Bags for Use in PatientControlled Analgesia Pumps for Postoperative Pain Management. International Journal of Pharmaceutical Compounding 10: 69-73.

9. International Conference on Harmonisation: $\mathrm{ICH}$ Harmonised Tripartite Guideline (2003) Stability testing of new drug substances and products. Q1A(R2) current step 4 version.

10. Le Hoang MD, Sarbach C, Prognon P, Delvordre P, Mignot A, et al. (1998) Stability of morphine hydrochloride solution in the PCA systems portable disposable: Interaction containment. J Clinical Pharmacy 17: 35-39.

11. Hung CT, Young M, Gupta PK (1988) Stability of morphine solutions in plastic syringes determined by reversed-phase ion-pair liquid chromatography. J Pharm Sci. 77: 719-723.

12. International Conference on Harmonisation: $\mathrm{ICH}$ Harmonised Tripartite Guideline (2005) Validation of analytical procedures: text and methodology. Q2(R1) current step 4 version.

13. Hubert P, Nguyen-Huu JJ, Boulanger B, Chapuzet E, Cohen N, et al. (2007) Harmonization of strategies for the validation of quantitative analytical procedures. A SFSTP proposal--part III. J Pharm Biomed Anal. 45: 82-96.

14. Yeh SY, Lach JL (1961) Stability of morphine in aqueous solution. III. Kinetics of morphine degradation in aqueous solution. J Pharm Sci 50: 35-42.

15. Lee G, Sabra K (2006) Stability of morphine sulphate in ANAPA Plus ambulatory infusion device and PEGA infusion sets. European J Hospital Pharm Sci 12 $76-80$.

16. Hildebrand KR, Elsberry DD, Hassenbusch SJ (2003) Stability and compatibility of morphine-clonidine admixtures in an implantable infusion system. J Pain Symptom Manage 25: 464-471

17. Vermeire A, Remon JP (1997) The solubility of morphine and the stability of concentrated morphine solutions in glass, polypropylene syringes and PVC containers. International Journal of Pharmaceutics 146: 213.

18. Remington (1995) The Science and Practice of Pharmacy (1995) Chapter 19 Interfacial Phenomena, Adsorption on Solid Surfaces from Solution (19thedn) $1: 250$. 